\title{
Mencari Jejak-jejak Autograf Perjanjian Lama di dalam Septuaginta
}

\author{
Brando V. Kondoj* \\ *Mahasiswa program studi Magister Teologi di STT-SAAT, Malang. \\ Email: brandovallentino@yahoo.co.id
}

\begin{abstract}
Abstrak: Untuk sekian lama, Septuaginta sebagai terjemahan Kitab Suci Ibrani yang pertama telah dipinggirkan dan tidak memperoleh tempat dalam usaha untuk mencari autograf (naskah asli Alkitab) Perjanjian Lama yang telah lama hilang itu. Namun demikian, perkembangan terbaru dalam studi terhadap naskah-naskah kuno Alkitab justru menunjukkan bahwa Septuaginta memiliki sumbangsih besar dalam pencarian autograf Perjanjian Lama. Hal ini dibuktikan melalui penggunaan metode kritik tekstual oleh para sarjana Alkitab, yakni dengan melakukan penelitian dan perbandingan terhadap naskah-naskah kuno Alkitab Perjanjian Lama, seperti Teks Masoret, Pentateukh Samaria, Gulungan Laut Mati, dan Septuaginta.

Kata-kata kunci: Septuaginta, autograf Perjanjian Lama, metode kritik tekstual, Teks Masoret, Pentateukh Samaria, Gulungan Laut Mati.

Abstract: For too long the Septuagint, the first translation of the Hebrew Old Testament, has been sidelined and not given a credible hearing in seeking to discern the text of the original autographs of the Old Testament which have been lost in antiquity. Even though that has been the case, the new direction in recent textual studies, which has focused on the meaning of the original autographs of the Old Testament, has recognized that the Septuagint has a significant contribution to make within this field of study. This position has been supported by Biblical scholars who have employed the Text Critical method in determining the authoritative text of the Old Testament. They employ the Text Critical method in their comparison of the Masoretic Text, the Samaritan Pentateuch, The Dead Sea Scrolls and most recently, the Septuagint to find traces of the original OT autographs.
\end{abstract}

Keywords: Septuagint, Old Testament autographs, text critical method, Masoretic Text, Samaritan Pentateuch, The Dead Sea Scrolls. 


\section{Pendahuluan}

Studi biblika adalah sebuah studi yang dinamis karena terus mengalami perkembangan dari waktu ke waktu. Penemuan yang terus terjadi di dalam bidang studi ini serta bidang-bidang lainnya yang berkaitan (mis. arkeologi) ikut memengaruhi pemahaman dan perspektif terhadap Alkitab, yakni Perjanjian Lama dan Perjanjian Baru. Pertanyaan-pertanyaan tentang asal-mula Alkitab, proses transmisi dan preservasinya, serta sejarah kompilasi kitabkitab di dalamnya mewarnai studi biblika dari tahun ke tahun. ${ }^{1}$ Hal ini membuktikan bahwa studi terhadap Alkitab bukanlah sebuah perkara mudah. Studi ini bersifat kompleks dan membutuhkan pemahaman yang menyeluruh terhadap berbagai segi di dalamnya. Salah satu isu yang paling ramai didiskusikan adalah isu mengenai autograf atau naskah asli Alkitab. ${ }^{2}$ Pencarian autograf Alkitab terus dilakukan oleh para sarjana yang berkecimpung dalam studi biblika. Mereka meyakini bahwa naskah asli Alkitab yang telah lama hilang itu dapat ditemukan dalam naskah-naskah Alkitab yang menjadi dasar penerjemahan versi-versi Alkitab modern. Lantas bagaimana caranya? Yakni dengan kembali kepada naskah-naskah kuno Alkitab. Naskah-naskah kuno Alkitab seperti Teks Masoret/Masoretic Text (MT), Pentateukh Samaria, Targum, Septuaginta, dan Gulungan Laut Mati (The Dead Sea Scrolls/DSS) menjadi objek penelitian dan perbandingan untuk mencari autograf Alkitab.

Tulisan ini secara khusus menyoroti Septuaginta (LXX) dan upaya pencarian autograf

${ }^{1}$ Lih. Craig A. Evans, "Introduction," dalam Exploring the Origins of the Bible: Canon Formation in Historical, Literary, and Theological Perspective, ed. Craig A. Evans \& Emanuel Tov (Grand Rapids: Baker, 2008), 15.

${ }^{2}$ Secara sederhana, autograf dapat diartikan sebagai naskah asli Alkitab (the original copy of the Bible), yakni naskah paling awal sebelum akhirnya mengalami penyalinan demi penyalinan. Sebagaimana akan dijelaskan dalam tulisan ini, salinan-salinan dari naskah awal Alkitab ini tanpa terhindarkan mengandung kesalahan-kesalahan tertentu, baik yang disengaja oleh penyalinnya maupun tidak. Naskah asli Alkitab (autograf) tersebut berusaha diperoleh kembali melalui usaha-usaha para sarjana biblika dengan menggunakan metode kritik tekstual. di dalam salah satu naskah kuno terjemahan Alkitab ini. Septuaginta telah lama dipandang sebagai naskah Alkitab yang korup dan tidak dapat diandalkan. Namun, pandangan ini mulai memperoleh perspektif baru karena penelitian-penelitian yang terus dilakukan. ${ }^{3}$ Penulis meyakini bahwa Septuaginta adalah sebuah sumber berharga bagi pencarian autograf yang telah lama hilang itu. Keyakinan ini didasarkan pada kenyataan bahwa Septuaginta adalah terjemahan pertama dari Kitab Suci Ibrani. Selain fakta tersebut, keyakinan penulis didorong oleh penelitian-penelitian yang dilakukan sarjana-sarjana biblika, seperti Emanuel Tov. Tov meyakini bahwa Septuaginta memiliki nilai khusus dalam upaya menemukan autograf Alkitab, khususnya dalam perbandingan dengan teks-teks dalam naskah MT. ${ }^{4}$ Penelitian dalam studi biblika ini semakin menemukan arahnya yang jelas dengan ditemukannya naskah-naskah Gulungan Laut Mati pada 1948. Ketiga naskah kuno ini, yakni MT, LXX ${ }^{5}$ dan DSS menjadi bahan utama para ahli dalam penelitian dan perbandingan teks-teks Alkitab untuk menemukan autograf Alkitab.

\footnotetext{
${ }^{3}$ Lee M. McDonald, seorang sarjana biblika, mengatakan bahwa LXX untuk waktu yang panjang telah dipinggirkan, bahkan ditolak, karena dianggap jauh lebih rendah daripada MT. Di beberapa seminari Kristen yang konservatif, LXX dilihat sebagai sumber kedua saja dan tidak banyak digunakan. LXX dianggap hanya terjemahan dari naskah asli Alkitab Ibrani (The Biblical Canon: Its Origin, Transmission, and Authority [Peabody: Hendrickson, 2007], 124).

${ }^{4}$ Penulis sepakat dengan niat dan usaha Tov yang berusaha menjadikan Septuaginta sebagai sumber analisis literer terhadap Kitab Suci Ibrani (lih. Emanuel Tov, "Septuagint as a Source for the Literary Analysis of Hebrew Scripture," dalam Exploring the Origins of the Bible, 31-56). Tov adalah seorang sarjana biblika kenamaan. Ia melakukan penelitian-penelitian di bidang Alkitab, juga terhadap Septuaginta secara mendalam. Ia memperoleh gelar Ph.D dari Hebrew University, Yerusalem. Beliau adalah Profesor J. L. Magnes bidang Alkitab di universitas yang sama. Tov telah menjadi editor kepala dari The Dead Sea Scrolls Publication Project sejak tahun 1990 dan terlibat dalam Hebrew University Bible Project dan The Computer Assisted Tools for Septuagint Studies Project, Universitas Pennsylvania. Ia menulis atau menjadi editor lebih dari 20 buku (ibid., 10).
}

${ }^{5}$ Beberapa sarjana biblika menggunakan juga istilah Old Greek untuk menunjuk kepada Septuaginta (LXX). 


\section{Misi Pencarian Autograf}

Alkitab, baik Perjanjian Lama maupun Perjanjian Baru, mengalami proses yang panjang sebelum sampai pada bentuknya yang sekarang. Dalam rangka pemeliharaan, teks-teks Alkitab yang ada sekarang sebelumnya telah mengalami proses penyalinan yang berulangulang. Proses penyalinan naskah yang dilakukan secara berulang-ulang ini mengalami kesalahan-kesalahan tertentu dalam pelaksanaannya. I Nyoman Murah mengatakan:

Berabad-abad lamanya naskah-naskah itu disalin berulang-ulang dengan tangan (disalin selama kurang lebih 1400 tahun), sebab pada waktu itu memang belum ada percetakan. Dengan disalinnya naskah-naskah itu tentu banyak kesalahan-kesalahan yang menyusup ke dalamnya. Memang tidak mungkin (sulit) menyalin sesuatu tanpa kesalahan. Misalnya bila kita menyalin satu atau dua halaman buku, maka pasti terjadi kesalahan atau kekeliruan dalam menulis sebuah kata atau kadang-kadang si penyalin memendekkan suatu kata. Ada kesalahan yang tidak disengaja, ada juga kesalahan yang disengaja, yang dibuat atas dasar bermacam-macam pertimbangan. Misalnya, cara menulis huruf-huruf dahulu berbeda dengan cara menulis huruf-huruf kemudian. Dari bentuk kuno kepada bentuk baru, boleh jadi penulis itu keliru, atau bisa jadi bentuk huruf lama itu agak kabur/korup. Ada juga konsonan-konsonan Ibrani yang hampir sama bentuknya, sehingga para penyalin mudah keliru. Selain kekeliruan/kesalahan menyalin konsonan yang dapat merubah arti kata dan maksud kalimat, maka ada kesulitan-kesulitan lain lagi, yaitu pemahaman kata yang berakar pada kebudayaan dan kebiasaan setempat pada zamannya. Setiap kata atau ungkapan mempunyai pemahaman sendiri pada tempat dan zaman tertentu. ${ }^{6}$

Hal ini mendorong para sarjana biblika melakukan apa yang disebut sebagai kritik tekstual,

${ }^{6}$ I Nyoman Murah, "Kritik Teks, Apa Itu?," Forum Biblika 3 (Oktober 1992): 1. seperti dikatakan Lee M. McDonald, "Many mistakes and even deliberate changes were made in the production of these manuscripts, and, as a result, a new craft called 'textual criticism' emerged in the church to determine the original wording of the biblical text." " Pendekatan kritik tekstual ini dimaksudkan untuk menetapkan bentuk asli dari teks Alkitab sebelum berbagai bentuk kesalahan, baik yang disengaja maupun tidak, masuk dalam naskah aslinya.

Kata-kata asli (original word) yang disebutkan oleh McDonald lebih dikenal dengan sebutan autograf atau naskah asli Alkitab. Autograf adalah manuskrip asli dari teks Alkitab yang ditulis atau didiktekan oleh penulis Alkitab sendiri. ${ }^{8}$ Pemahaman ini menjadikan penelitian dan pencarian autograf suatu hal yang sangat penting dalam studi biblika. Eugene Ulrich mengatakan:

What form of the text, then, should be the object of our search? 'The original text' is commonly listed as the object of textual research, the object of text criticism, and the object of those who produce translations of the Holy Bible for religious, literary, and historical purpose. ${ }^{9}$

Pendapat Ulrich menguatkan kepentingan untuk meneliti naskah-naskah kuno Alkitab demi mencari autograf, sebab baginya autograf adalah objek dari penelitian tekstual. Seperti yang telah disebutkan di atas, pencarian autograf ini dilakukan dengan menggunakan metode kritik tekstual. Kritik tekstual adalah sebuah disiplin yang mencoba menemukan kembali salinan asli (autograf) dari bagian-bagian literatur (Alkitab) dengan membandingkan salinan-salinan yang tersedia, di mana di dalam salinan-salinan tersebut secara tak terhindarkan terdapat kesalahankesalahan. ${ }^{10}$ Kritik Tekstual dilakukan terha-

\footnotetext{
${ }^{7}$ The Biblical Canon, 4.

${ }^{8}$ Allen C. Myers, ed., The Eerdmans Bible Dictionary (Grand Rapids: Eerdmans, 1987), 108.

${ }^{9}$ Eugene Ulrich, The Dead Sea Scrolls and the Origins of the Bible (Grand Rapids: Eerdmans, 1999), 12.

${ }^{10}$ Ralph W. Klein, Textual Criticism of the Old Testament: The Septuagint after Qumran (Philadelphia: Fortress, 1974), vii.
} 
dap teks-teks Alkitab secara teliti. Berkenaan dengan hal ini, I Nyoman Murah mengemukakan pendapatnya:

Kritik Tekstual adalah ilmu pengetahuan dan cara bekerja dengan pengawasan yang teliti terhadap teks-teks (teks-teks asli dalam Alkitab) . . . maksud dan tujuan ilmu kritik tekstual adalah berusaha menelusuri, mengusut, dan mencari keteranganketerangan tentang peralihan atau perubahan-perubahan yang telah terjadi dan menemukan kembali bentuk-bentuk teks yang paling awal. ${ }^{11}$

Dalam menentukan teks Alkitab mana yang dianggap mewakili tradisi teks yang paling dekat dengan naskah asli Alkitab, prinsipprinsip berikut telah menjadi pegangan yang penting:

1. Pada umumnya teks yang susunan atau bunyinya lebih sulit dianggap mewakili tradisi teks yang lebih dekat kepada teks asli, sebab seorang penyalin niscaya akan selalu melakukan usaha (tambahan) membuat teks yang disalinnya lebih mudah dimengerti, dan bukan sebaliknya.

2. Teks yang susunannya lebih pendek biasanya dianggap mewakili tradisi teks yang lebih dekat kepada teks asli dibanding teks yang lebih panjang, sebab setiap penyalin dianggap akan selalu berusaha mempermudah pemahaman atas teks yang disalinnya dengan jalan menambahkan keterangan-keterangan pada teks yang bersangkutan.

3. Varian teks yang mendapat dukungan kesaksian lebih banyak versi atau naskah-naskah tua dianggap sebagai varian teks yang lebih dekat kepada teks asli dibanding varian teks yang sedikit saja mendapat dukungan kesaksian dari naskah-naskah tua yang ada. ${ }^{12}$

\footnotetext{
${ }^{11}$ Murah, "Kritik Teks, Apa Itu?," 2-3.

${ }^{12}$ Ishak P. Lambe, "Kritik Teks Naskah Perjanjian Lama: Uraian Umum tentang Kritik Teks sebagai Sebuah Metode Penelitian Kritis terhadap Naskah-Naskah Perjanjian Lama," Forum Biblika 3 (Oktober 1992): 30.
}

Kepentingan Septuaginta dalam studi biblika sangat erat kaitannya dengan metode kritik tekstual Alkitab. Jejak-jejak autograf di dalamnya akan dapat dilihat melalui penggunaan metode ini. Sebelum itu, penting untuk melihat sejarah Septuaginta. Asal-usul Septuaginta akan sangat menentukan mengapa naskah kuno terjemahan Alkitab ini dipakai dalam pencarian autograf Alkitab, terutama dalam perbandingannya dengan naskah MT.

\section{Asal-usul Septuaginta}

Septuaginta sebagai terjemahan Kitab Suci Ibrani pertama menyimpan banyak kisah menarik dalam proses penerjemahannya. Dokumen paling terkenal yang berisi asalusul LXX adalah Surat Aristeas. ${ }^{13}$ Surat Aristeas ditulis di Aleksandria dan mengisahkan proses penerjemahan Pentateukh dari bahasa Ibrani ke dalam bahasa Yunani. Dikisahkan bahwa Ptolemaeus II Filadelfos menyuruh Demetrius, penjaga perpustakaan Aleksandria, untuk melengkapi perpustakaan tersebut dengan semua salinan buku di seluruh dunia. Demetrius kemudian menganjurkan supaya kitab-kitab Hukum Taurat juga diterjemahkan ke dalam bahasa Yunani. Dalam bukunya, McDonald mengutip isi Surat Aristeas untuk menerangkan hal ini:

On his appointment as keeper of the king's [Ptolemy II Philadelphus, 285-247 B.C.E] library, Demetrius of Phalerum undertook many different negotiations aim at collecting, if possible, all the books in the world. By purchase and translation he brought to successful conclusion, as far as lay in his power, the king's plan. We were present when the question was put to him, "How many thousand books are there (in the royal library)?" His reply was, "Over two hundred thousand, $O$ King. I shall take urgent steps to increase in a short time the total to five hundred thousand. Information has reached me that the lawbooks of the Jews are worth translation

\footnotetext{
${ }^{13}$ Untuk terjemahan Surat Aristeas dalam bahasa Inggris, lih. Robert J. H. Shutt, "Letter of Aristeas," dalam The Old Testament Pseudepigrapha, ed. James H. Charlesworth (New York: Doubleday, 1985), 2:7-34.
} 
and inclusion in your royal library." (Letter of Aristeas 9-10). ${ }^{14}$

Surat Aristeas ingin menunjukkan bahwa Raja Ptolemaeus memiliki andil yang besar dalam seluruh proses untuk menerjemahkan Pentateukh ke dalam bahasa Yunani karena Demetrius bekerja di bawah otoritas dan perintahnya. Demi tujuannya ini, Ptolomeus kemudian mengirimkan surat kepada Eleazar, Imam Besar orang Yahudi di Yerusalem dan memintanya mengutus 72 orang (enam orang dari setiap suku Israel) yang memiliki keahlian dalam Hukum Taurat untuk melakukan pekerjaan penerjemahan itu. Demetrius membawa ke-72 orang utusan dari Yerusalem ini ke sebuah pulau dan menempatkan mereka di sebuah gedung mewah untuk menerjemahkan kelima kitab Musa. Mereka menyelesaikan pekerjaan mereka dalam waktu 72 hari dengan hasil kerja yang luar biasa. Terjemahan tersebut dibacakan di hadapan jemaat Yahudi yang tinggal di Aleksandria dan disambut dengan antusias. Orang Yahudi Aleksandria kemudian meminta salinan tersebut untuk dipakai di dalam komunitas mereka. ${ }^{15}$

Harus diakui, kebanyakan isi dari Surat Aristeas tidak historis. Para sarjana sepakat bahwa Surat Aristeas ditulis satu abad sesudah penerjemahan Pentateukh ke dalam bahasa Yunani, yakni pada abad ke-2 SM.

\footnotetext{
${ }^{14}$ The Biblical Canon, 44-45.

${ }^{15}$ Kisah kemunculan Septuaginta berkembang lebih jauh dalam tradisi Yahudi dan Kristen. Philo, seorang filsuf Yahudi dari abad pertama Masehi, mengidentifikasikan nama pulau tempat penerjemahan dilakukan sebagai pulau Pharos. Ia menambahkan bahwa ke-72 orang yang melakukan pekerjaan penerjemahan itu adalah para nabi dan imam yang bekerja di bawah inspirasi ilahi. Epiphanius, seorang Kristen yang hidup di abad ke-4 Masehi menyebutkan bahwa ke-72 penerjemah dibagi menjadi tiga puluh enam pasang dan masing-masing menerjemahkan kitab-kitab Perjanjian Lama. Sesudah dibandingkan, semua terjemahan identik dan tidak ditemukan satupun ketidakcocokan. Nama "Septuaginta" sendiri-yang berarti 70-muncul dan lebih mendominasi dalam tradisi Kristen. Angka 70 dianggap lebih bermakna karena menunjuk pada 70 tua-tua yang bersama-sama Musa di Gunung Sinai serta 70 orang yang diutus Yesus seperti yang terdapat dalam Lukas pasal 10 (lih. Leonard J. Greenspoon, "Mission to Alexandria: Truth and Legend About the Creation of the Septuagint, the First Bible Translation," Bible Review 5, no. 4 [August 1989]: 37, 40).
}

Leonard J. Greenspoon mengatakan bahwa penulis Surat Aristeas bertujuan mempertahankan otoritas terjemahan Yunani dari Pentateukh. Ia berargumen, "that purpose lies implicit in much of the letter."16 Sebagian besar sarjana bahkan sepakat bahwa Surat Aristeas ditulis untuk mempertahankan keyahudian secara umum dan terjemahan Yunani secara khusus. ${ }^{17}$ Pendapat beberapa ahli ini didasarkan pada bukti-bukti di dalam Surat Aristeas sendiri. Dikisahkan bahwa sesudah terjemahan tersebut dibacakan dan menerima sambutan yang luar biasa, para imam dan tua-tua Yahudi di Aleksandria menetapkan bahwa barangsiapa menambahkan atau membuat perubahan dalam teks yang telah diterjemahkan itu akan dikutuk. ${ }^{18}$

Meskipun surat Aristeas berisi kisah-kisah legendaris yang tidak sepenuhnya historis, surat ini memberikan sumbangan data yang cukup mengenai Septuaginta. Berdasarkan data arkeologis yang diperoleh di Mesir dan pemeriksaan materi manuskrip LXX, para sarjana sepakat dengan keterangan yang diberikan Surat Aristeas bahwa Septuaginta sebagai terjemahan Pentateukh ditulis di Aleksandria dan berasal dari abad ke-3 SM. ${ }^{19}$ Ishak P. Lambe mengemukakan pendapatnya tentang hal ini:

Jikapun kita hendak menerima sesuatu yang historis dalam surat tersebut, maka satu-satunya adalah mengenai motivasi penerjemahan itu, yaitu “. . . hukum orang Yahudi (yaitu Pentateukh) berharga untuk ditempatkan di dalam perpustakaan kerajaan. .. ," dalam arti bahwa tradisi-tradisi pemikiran keagamaan orang Yahudi yang terdapat di dalam PL dihargai dan menarik perhatian dunia bukan Yahudi, dalam hal ini dunia Helenis Yunani. Surat Aristeas memberi pula keterangan yang dapat dipercaya dalam hal menyebut kota Alek-

\footnotetext{
${ }^{16}$ Ibid., 40.

${ }^{17}$ Karen H. Jobes dan Moisés Silva, Invitation to the Septuagint (Grand Rapids: Baker, 2000), 34.

${ }^{18}$ Greenspoon, "Mission to Alexandria," 40.

${ }^{19}$ Ibid.
} 
sandria sebagai pusat di mana pekerjaan penerjemahan itu dilakukan. ${ }^{20}$

Dari hal-hal yang telah dikemukakan di atas, beberapa fakta historis yang akurat tentang Septuaginta dapat ditarik dari Surat Aristeas, sebagaimana yang dikemukakan oleh Ralph W. Klein: (1) Terjemahan tersebut mulai dikerjakan pada abad ke-3 SM; (2) Aleksandria adalah tempat asal-mulanya; dan (3) Pentateukh adalah yang pertama diterjemahkan. ${ }^{21}$ Untuk menjelaskan butir-butir ini pendapat Lambe sangat baik untuk dikutip:

Pada kenyataannya Septuaginta adalah karya terjemahan PL yang dikerjakan dalam masa yang cukup panjang. Menurut perkiraan para ahli, Septuaginta berasal dari masa sekitar pertengahan abad ke-3 SM. Orang-orang Yahudi yang berada di Mesir, yang "pusat"nya adalah kota Aleksandria, tidak lagi mengerti dengan baik isi kitab Taurat Musa yang ditulis di dalam bahasa Ibrani. Mereka membutuhkan suatu "penjelasan" isi kitab suci itu di dalam bahasa yang dapat mereka mengerti, yaitu bahasa Yunani (Koine), yang merupakan lingua franca di seluruh Kekaisaran Romawi pada masa itu. . . . Bagian PL yang mula-mula mendapat perhatian untuk "dijelaskan" dalam bahasa Yunani adalah kitab-kitab Taurat Musa (=Pentateukh). Kemudian satu per satu dari kitab lainnya menyusul. ${ }^{22}$

Hal ini senada dengan pendapat Karen $\mathrm{H}$. Jobes dan Moisés Silva. Mereka meyakini bahwa Pentateukh diterjemahkan pada tahun 250 SM di Aleksandria dan kitab-kitab lainnya dalam Kitab Suci Ibrani diterjemahkan sepanjang dua abad selanjutnya. ${ }^{23}$

Dari sejarah yang telah dikemukakan, makin jelaslah posisi penting Septuaginta dalam studi biblika. Septuaginta memegang peranan penting dalam pencarian autograf yang telah

\footnotetext{
${ }^{20}$ Lambe, "Kritik Teks Naskah Perjanjian Lama," 24.

${ }^{21}$ Klein, Textual Criticism of the Old Testament, 2.

${ }^{22}$ Lambe, "Kritik Teks Naskah Perjanjian Lama," 24.

${ }^{23}$ Jobes dan Silva, Invitation to the Septuagint, 29.
}

lama hilang dalam perbandingannya dengan MT. Pernyataan ini semakin kuat dengan keyakinan bahwa dalam kisah asal-mulanya bahan dasar ${ }^{24}$ yang dipakai untuk penerjemahan LXX berasal dari Yerusalem, seperti yang dikemukakan Greenspoon, "They worked from Hebrew manuscripts that had the approval and authority of the chief Jewish religious functionary, the high priest in Jerusalem." 25 Lambe mengatakan:

Melihat asal-usulnya, Septuaginta jelas merupakan dokumen yang sangat penting untuk menguji keotentikan teks-teks masoretis PL. Asal-usulnya yang ditempatkan beberapa abad sebelum Kristus itu, yang ternyata lebih tua dari teks-teks masoretis itu sendiri, menempatkan versi Septuaginta itu lebih dekat kepada teksteks PL pre-masoretis, yaitu teks-teks PL yang menjadi bahan dasar kaum masoret Yahudi menyusun teks baku itu. ${ }^{26}$

\section{Versus MT: Sebuah Usaha Mencari Autograf}

Naskah Alkitab yang akan diteliti dan dibandingkan adalah naskah Teks Masoret dan naskah Septuaginta. Mengapa Teks Masoret (MT)? Hal ini karena MT adalah versi resmi dari Kitab Suci Ibrani, atau Perjanjian Lama, bagi agama Yahudi dan agama Kristen sejak awal abad Pertengahan. ${ }^{27}$ MT adalah teks Perjanjian Lama yang mendasari baik BHK (Biblia Hebraica ed. Rudolf Kittel) maupun BHS (Biblia Hebraica Stuttgartensia). Sejarah MT dimulai pada sekitar tahun $100 \mathrm{M}$ dan mencapai bentuk finalnya pada sekitar abad ke-9 atau $10 \mathrm{M}$. MT sendiri memperoleh sistem vokalisasi yang baku pada sekitar abad

\footnotetext{
${ }^{24}$ Bahan dasar yang dimaksud ini lebih dikenal dengan sebutan Hebrew Vorlage atau Vorlage saja. Jobes dan Silva memberi definisi Vorlage sebagai "the Hebrew parent text from which a text was translated" (ibid., 21). Dengan kata lain, Hebrew Vorlage adalah teks Ibrani yang dijadikan bahan dasar dalam proses penyalinan dan penerjemahan sebuah naskah Alkitab.

${ }^{25}$ Greenspoon, "Mission to Alexandria," 36.

${ }^{26}$ Lambe, "Kritik Teks Naskah Perjanjian Lama," 25.

${ }^{27}$ Evans, "Introduction," 16.
} 
ke-14 M. ${ }^{28}$ Dalam perbandingan dua naskah Alkitab ini untuk mencari autograf, pendapat Ernst Wurthwein patut dipertimbangkan:

The Hebrew text which we have today has been altered from its original form by many circumstances and undoubtedly contains many corruptions. Consequently the versions which enable us to reconstruct an older Old Testament text and to correct errors are very important. ${ }^{29}$

Argumen Wurthwein adalah bahwa versiversi Perjanjian Lama harus dipakai untuk merekonstruksi teks Perjanjian Lama yang lebih tua dan untuk mengoreksi kesalahankesalahan yang ada di teks Ibrani Perjanjian Lama. Septuaginta, sebagaimana telah diterangkan di atas, memiliki peran penting dalam usaha mencari autograf Perjanjian Lama. Kepentingan ini dijelaskan oleh Jobes dan Silva:

The Greek version also has great value for the study of the Hebrew text. The issues surrounding this use of the version are quite complex, but the fact remains that the Septuagint was translated from some Hebrew text that was not identical to the Hebrew text we use today. That original Greek translation, which was produced much earlier than any surviving copy of the Hebrew Bible, is an indirect witness to its Vorlage, that is, the Hebrew parent text from which it was translated. In theory, the Septuagint should allow scholars to reconstruct that earlier Hebrew text, though in practice this activity is fraught with difficulties. ${ }^{30}$

Bagi Jobes dan Silva, Septuaginta memiliki kepentingan yang besar dalam perbandingannya dengan MT karena Septuaginta diterjemahkan dari teks Ibrani yang berbeda dari MT dan diproduksi lebih awal daripada salinan Alkitab Ibrani yang lain. Tov meli17

${ }^{28}$ Lihat Lambe, "Kritik Teks Naskah Perjanjian Lama,"

\footnotetext{
${ }^{29}$ Ernst Wurthwein, The Text of the Old Testament (Grand Rapids: Eerdmans, 1995), 48.
}

${ }^{30} \mathrm{McD}$ onald, Invitation to the Septuagint, 20-21. hat perlunya teks-teks lain di samping MT dalam rangka mengerti dan memahami Perjanjian Lama. Ia mengatakan, "My own intuition tells me that more often than not the LXX reflects an earlier stage than Masoretic Text both in the literary shape of the biblical books and in small details." ${ }^{11}$ Tov berkeyakinan bahwa LXX mencerminkan tingkatan yang lebih awal dalam hal bentuk kitab maupun detaildetailnya dibandingkan MT. Dalam hubungannya dengan hal ini, McDonald menuliskan komentar tentang penemuan Tov dalam studi LXX dan MT di dalam artikelnya:

He has discovered that the Old Greek, the Dead Sea Scrolls, and other ancient texts sometimes depend on a more ancient and reliable Hebrew text than does the MT. He suggests that we may be able to discover an earlier form of the biblical text through a careful investigation not only of the Masoretic Text, but also the Old Latin, the Greek Bible, the Samaritan Pentateuch, and the Dead Sea Scrolls. He argues that in some cases, these texts may provide an earlier witness than what we find in the MT, the standard biblical text for most Jews as well as for most biblical scholars today. ${ }^{32}$

Tov melihat bahwa naskah-naskah Alkitab yang lain, di luar Teks Masoret, memiliki signifikansi dalam penelitian Alkitab. Naskahnaskah Alkitab yang lain ini kadang-kadang lebih bergantung kepada teks Ibrani yang lebih tua dan dapat diandalkan dibandingkan MT. McDonald kemudian menambahkan komentar pribadinya:

Traditionally, conservative Christian biblical scholars have spoken disparagingly about the Septuagint (LXX) and in favor of the Masoretic Text, but scholars more recently have begun asking whether in some instances the Old Greek might preserve a more ancient text than does the MT. We should remember that the Greek Bible was the Bible of early

\footnotetext{
${ }^{31}$ Dikutip dalam Lee M. McDonald, "Wherein Lies Authority? A Discussion of Books, Texts, and Translations," dalam Exploring the Origins of the Bible, 212 n. 14.

${ }^{32}$ Ibid., 212.
} 
Christianity and, as most seminary students already know, it was used by the New Testament writers in some 94 percent of their citations from the Jewish Scriptures. ${ }^{33}$

McDonald menjelaskan bahwa Septuaginta kini telah dilihat oleh para sarjana sebagai naskah Alkitab yang penting karena bagianbagian teksnya dianggap sebagai teks yang lebih kuno dibandingkan Teks Masoret. Kepentingan Septuaginta menjadi semakin besar sebab penelitian menunjukkan bahwa kutipan-kutipan Perjanjian Baru kepada Perjanjian Lama lebih banyak diambil dari Septuaginta. Beberapa pendapat ini semakin menguatkan peranan Septuaginta di samping naskah-naskah Alkitab lainnya. Walaupun begitu, Jobes dan Silva mengingatkan bahwa ketika membandingkan Septuaginta dengan MT dan kemudian ditemukan perbedaanperbedaan, beberapa hal ini mungkin adalah faktor penyebabnya:

1. The Hebrew Vorlage from which it was translated was different from the Hebrew text extant today.

2. The translation process was unprecedented and therefore does not reveal a pattern.

3. The translator made a mistake.

4. The translator had an interpretative bias.

5. Some complicated combination of these circumstances affected the resulting translation. $^{34}$

Kelima poin ini adalah hal-hal yang dianggap Jobes dan Silva menyebabkan perbedaan antara Septuaginta dan Teks Masoret, yakni perbedaan "teks ibu," proses penerjemahan, bias penerjemah, dan interpretasinya. Halhal ini memang melekat pada Septuaginta dan Teks Masoret sebagai produk terjemahan yang berasal dari suatu tempat dan kurun waktu tertentu, di mana situasi dan kondisinya dapat saja memengaruhi proses penerjemahannya. Sebagaimana dikatakan Wurthwein, "every translator is a child of a particular time and of a particular culture." 35

\footnotetext{
${ }^{33}$ Ibid.

${ }^{34}$ Jobes dan Silva, Invitation to the Septuagint, 92.

${ }^{35}$ Wurthwein, The Text of the Old Testament, 48.
}

\section{Perbandingan Teks LXX dan MT ${ }^{36}$}

Dalam perbandingan teks Alkitab antara Septuaginta dan Teks Masoret, kitab Yeremia adalah yang cukup menonjol. Versi-versi utama yang kuno dari kitab Yeremia yang masih bertahan adalah versi Teks Masoret, Septuaginta, dan 4QJerb, d (DSS). ${ }^{37}$ Klein mengatakan, "The LXX of Jeremiah differs dramatically from MT, lacking one word in every eight, or about 2700 words for the whole book." 38 Tov memberikan keterangan yang hampir sama dengan beberapa penjelasan:

The LXX version differs from the MT in two central matters: the order of the chapters and verses and the length of the text. The $L X X$ is shorter than the MT by one-sixth. It lacks words, phrases, sentences, and entire sections of the MT. The shortness of this text was considered enigmatic throughout the scholarly inquiry of the Greek text, but is now supported by the Hebrew 4 QJer ${ }^{b, d} .{ }^{39}$

Perbedaan yang ditunjukkan teks Yeremia LXX dan MT meliputi urutan pasal dan ayatayat serta panjangnya teks. Teks Yeremia LXX didukung oleh teks Yeremia DSS. Pasal 10, pasal 43, dan pasal 27 akan dipakai untuk menunjukkan perbedaan-perbedaan antara naskah Septuaginta dan Teks Masoret kitab Yeremia.

\footnotetext{
${ }^{36}$ Bagian-bagian Alkitab yang dipilih dan ayat-ayatnya yang dicantumkan didasarkan pada penelitian dan terjemahan yang dilakukan oleh Tov (lih. Emanuel Tov, "Septuagint as a Source for the Literary Analysis of Hebrew Scripture," dalam Exploring the Origins of the Bible, 31-56). Teks-teks Septuaginta dan Teks Masoret hasil terjemahan Tov dibandingkan oleh penulis dengan terjemahan Septuaginta ke dalam bahasa Inggris karya Sir Lancelot C. L. Brenton dan terjemahan Teks Masoret ke dalam bahasa Inggris yang diterbitkan oleh The Jewish Publication Society of America.

${ }^{37}$ Tov, "Septuagint as a Source," 31-56.

${ }^{38}$ Klein, Textual Criticism of the Old Testament, 20.

${ }^{39}$ Tov, "Septuagint as a Source," 35, 36.
} 


\section{Yeremia 10:1-11}

\begin{tabular}{|c|c|}
\hline TEKS LXX & TEKS MT \\
\hline $\begin{array}{l}{ }^{1} \text { Hear the word which the LORD has spoken to } \\
\text { you, O House of Israel! }\end{array}$ & $\begin{array}{l}{ }^{1} \text { Hear the word which the LORD has spoken to } \\
\text { you, O House of Israel! }\end{array}$ \\
\hline $\begin{array}{l}{ }^{2} \text { Thus said the LORD: Do not learn to go the way } \\
\text { of the nations, and do not be dismayed by por- } \\
\text { tents in the sky; let the nations be dismayed by } \\
\text { them! }\end{array}$ & $\begin{array}{l}{ }^{2} \text { Thus said the LORD: Do not learn to go the way } \\
\text { of the nations, and do not be dismayed by por- } \\
\text { tents in the sky; let the nations be dismayed by } \\
\text { them! }\end{array}$ \\
\hline $\begin{array}{l}\text { 'For the laws of the nations are delusions; for it is } \\
\text { the work of a craftsman's hands. He cuts down a } \\
\text { tree in the forest with an ax, }\end{array}$ & $\begin{array}{l}{ }^{3} \text { For the laws of the nations are delusions; for it is } \\
\text { the work of a craftsman's hands. He cuts down a } \\
\text { tree in the forest with an ax, }\end{array}$ \\
\hline $\begin{array}{l}{ }^{4} \mathrm{He} \text { adorns it with silver and gold, He fastens it } \\
\text { with nails and hammer, so that it does not totter. }\end{array}$ & $\begin{array}{l}{ }^{4} \text { He adorns it with silver and gold, He fastens it } \\
\text { with nails and hammer, so that it does not totter. }\end{array}$ \\
\hline \multirow[t]{4}{*}{$\begin{array}{l}{ }^{5} \text { They are like a scarecrow in a cucumber patch, } \\
\text { they cannot speak. They have to be carried, for } \\
\text { they cannot walk. Be not afraid of them, for they } \\
\text { can do no harm; nor is it in them to do any good. }\end{array}$} & $\begin{array}{l}{ }^{5} \text { They are like a scarecrow in a cucumber patch, } \\
\text { they cannot speak. They have to be carried, for } \\
\text { they cannot walk. Be not afraid of them, for they } \\
\text { can do no harm; nor is it in them to do any good. }\end{array}$ \\
\hline & $\begin{array}{l}{ }^{6} \mathrm{O} \text { LORD, there is none like You! You are great } \\
\text { and Your name is great in power. }\end{array}$ \\
\hline & $\begin{array}{l}{ }^{7} \text { Who would not revere you, O King of the } \\
\text { nations? For that is Your due, since among all the } \\
\text { wise of the nations and among all their royalty } \\
\text { there is none like You. }\end{array}$ \\
\hline & $\begin{array}{l}{ }^{8} \text { But they are both dull and foolish; their doctrine } \\
\text { is but delusion; it is piece of wood, }\end{array}$ \\
\hline \multirow[t]{2}{*}{$\begin{array}{l}{ }^{9} \text { Silver beaten flat, that is brought from Tarshish, } \\
\text { and gold from Uphaz, the work of a craftsman } \\
\text { and the goldsmith's hands; their clothing is blue } \\
\text { and purple, all of them are the work of skilled } \\
\text { men. }\end{array}$} & $\begin{array}{l}{ }^{9} \text { Silver beaten flat, that is brought from Tarshish, } \\
\text { and gold from Uphaz, the work of a craftsman } \\
\text { and the goldsmith's hands; their clothing is blue } \\
\text { and purple, all of them are the work of skilled } \\
\text { men. }\end{array}$ \\
\hline & $\begin{array}{l}{ }^{10} \text { But the LORD is truly God: He is a living God, } \\
\text { the everlasting King. At His wrath, the earth } \\
\text { quakes, and nations cannot endure His rage. }\end{array}$ \\
\hline $\begin{array}{l}{ }^{11} \text { Thus shall you say to them: Let the gods, who } \\
\text { did not make heaven and earth, perish from the } \\
\text { earth and from under these heavens. }\end{array}$ & $\begin{array}{l}{ }^{11} \text { Thus shall you say to them: Let the gods, who } \\
\text { did not make heaven and earth, perish from the } \\
\text { earth and from under these heavens. }\end{array}$ \\
\hline
\end{tabular}




\section{Yeremia 43 (LXX 40):4-6}

Perbedaan-perbedaan yang menonjol di pasal 43 ini ada pada bentuk dari nama-nama yang disebutkan di dalamnya. Dalam naskah Teks Masoret, nama-nama panjang ditemukan: "Yohanan bin Kareah," "nabi Yeremia,"
"Gedalya bin Ahikam bin Safan." Sementara dalam Septuaginta dan naskah Gulungan Laut Mati, nama-nama pendek yang ditemukan: "Yohanan," "Yeremia," "nabi itu," "Gedalya," dan "Gedalya bin Ahikam."40

\begin{tabular}{|c|c|}
\hline TEKS LXX & TEKS MT \\
\hline $\begin{array}{l}{ }^{4} \text { So Johanan and all the army officers and the } \\
\text { rest of the people did not obey the LORD'S com- } \\
\text { mand to remain in the land of Judah. 'Instead, } \\
\text { Johanan and all the army officers took the entire } \\
\text { remnant of Judah-those who had returned from } \\
\text { all the countries to which they had been scattered } \\
\text { and had sojourned in the land of Judah, }{ }^{6} \text { men, } \\
\text { woman, and children; and the daughters of the } \\
\text { king and all the people whom Nebuzaradan had } \\
\text { left with Gedaliah son of Ahikam, as well as the } \\
\text { prophet Jeremiah and Baruch son of Neriah. }\end{array}$ & $\begin{array}{l}{ }^{4} \text { So Johanan son of Kareah and all the army } \\
\text { officers and the rest of the people did not obey } \\
\text { the LORD'S command to remain in the land of } \\
\text { Judah. 'Instead, Johanan son of Kareah and } \\
\text { all the army officers took the entire remnant } \\
\text { of Judah-those who had returned from all } \\
\text { the countries to which they had been scattered } \\
\text { and had sojourned in the land of Judah, }{ }^{6} \text { men, } \\
\text { woman, and children; and the daughters of the } \\
\text { king and all the people whom Nebuzaradan the } \\
\text { chief of the guards had left with Gedaliah son of } \\
\text { Ahikam son of Shaphan, as well as the prophet } \\
\text { Jeremiah and Baruch son of Neriah. }\end{array}$ \\
\hline
\end{tabular}

\section{Yeremia 27 (LXX 34):19-22}

Kisah dalam pasal 27 adalah tentang Yeremia yang menyampaikan firman TUHAN kepada Raja Zedekia supaya tunduk kepada Raja Nebukadnezar. Yeremia membawa pesan tentang kekuasaan Babel terhadap segala bangsa di sekitarnya, termasuk atas Yehuda, sebagai kehendak TUHAN sendiri. Berita yang disampaikan Yeremia sekaligus membantah nubuatan para nabi palsu yang justru mendorong raja untuk tidak menundukkan diri kepada kekuasaan Babel. Dalam teks ini akan terlihat perbedaan antara Septuaginta dan Teks Masoret.

\begin{tabular}{|c|c|}
\hline TEKS LXX & TEKS MT \\
\hline $\begin{array}{l}{ }^{19} \text { For thus said the Lord concerning the rest of the } \\
\text { vessels }{ }^{20} \text { which the king of Babylon did not take } \\
\text { when he exiled Jeconiah from Jerusalem. }{ }^{22} \text { They } \\
\text { shall be brought to Babylon declares the Lord. }\end{array}$ & $\begin{array}{l}{ }^{19} \text { For thus said the Lord of Hosts concerning } \\
\text { the columns, the tank, the stands and concern- } \\
\text { ing the rest of the vessels which remain in this } \\
\text { city, }{ }^{20} \text { which Nebuchadnezzar the king of Baby- } \\
\text { lon did not take when he exiled Jeconiah son of } \\
\text { Jehoiakim, king of Judah from Jerusalem to } \\
\text { Babylon, with all the nobles of Judah and Jeru- } \\
\text { salem- }{ }^{21} \text { thus said the Lord of Hosts, the God } \\
\text { of Israel, concerning the vessels remaining in } \\
\text { the House of the Lord, in the royal palace of } \\
\text { Judah and in Jerusalem: }{ }^{22} \text { They shall be brought } \\
\text { to Babylon and there they shall remain until } \\
\text { I take note of them-declares the Lord-and } \\
\text { bring them up and restore them to this place. }\end{array}$ \\
\hline
\end{tabular}

\footnotetext{
${ }^{40}$ Lih. ibid., 38.
} 


\section{Analisis Hasil Perbandingan Teks Yeremia} LXX dan MT

Dari ketiga bagian Alkitab yang dipilih sebagai ayat-ayat pembanding antara Septuginta dan MT, beberapa hal dapat ditarik. Pertama, bentuk teks dari naskah Septuaginta dan MT yang dibandingkan menunjukkan adanya perbedaan edisi. ${ }^{41}$ Teks LXX dan Qumran jauh lebih singkat daripada teks MT. Hal ini nampak jelas dari ketiga pasal kitab Yeremia yang dibandingkan. Kedua, perbedaan teks menunjukkan pemahaman dan kepentingan teologis penyalin naskah, dalam hal ini penyalin naskah MT. Pemahaman teologis MT tentang Tuhan sebagai Raja atas bangsa-bangsa yang harus dipuji nampak dalam pasal 10 . Tov mengatakan:

The Prophecy in edition II (MT) contains both mockery of the idols and praise of the Lord. The disdain of the idols refers to their inability to walk, speak, and move around, as well as the fact they are man-made. The mockery is included in verses 2-5, 8-9, 11, while the remaining verses 6-7 and 10 praise the Lord. The verses containing this praise are lacking in the $L X X$ and $4 Q J e r^{b}$, dating to the first half of the second century BCE. It is often assumed that the short edition I (the LXX AND 4QJer ${ }^{b}$ ) reflects the original text of this chapter, and that edition II (MT) reflects a later tradition in which the praise of the Lord has been added in order to stress the futility of the idols. ${ }^{42}$

Nubuatan dalam pasal 10 berisi ejekan kepada berhala-berhala (ada di dalam teks MT, LXX, dan 4QJer ${ }^{\mathrm{b}}$ ) dan pujian kepada Tuhan (yang tidak ada dalam LXX dan 4QJer ${ }^{\mathrm{b}}$ ). Tov meyakini bahwa LXX mencerminkan teks asli Alkitab dalam bagian ini.

Dalam komentarnya terhadap teks Yeremia pasal 10:1-11, Natalio F. Marcos menunjukkan kesamaan pandangan dengan Tov, PierreMaurice Bogaert, dan Jeremiah G. Janzen, sarjana-sarjana biblika yang telah melakukan

\footnotetext{
${ }^{41}$ Ibid., 36.

${ }^{42}$ Ibid., 36-37.
}

penelitian secara khusus terhadap teks Yeremia LXX dan MT. Marcos mengatakan:

The translator of Jeremiah did not shorten the Hebrew text as many exegetes had thought but instead, to judge from comparative study of these two texts, it was the redactor of the Masoretic Text who edited and expanded form of a text similar to the Vorlage of the $L X X$. Accordingly, Jeremiah-LXX reflects a first, shorter edition of Jeremiah, which is earlier than the second enlarged edition transmitted by the Masoretic Text. ${ }^{43}$

Beberapa sarjana biblika, dalam komentarkomentarnya, melihat pasal 10 kitab Yeremia ini sebagai bagian yang kontroversial, namun semua sampai pada pendapat yang sama, yakni bahwa bagian teks ini telah mengalami perluasan. ${ }^{44}$ Douglas R. Jones mengatakan bahwa bagian-bagian pujian dalam kitab Yeremia pasal 10:1-11, yakni ayat 6, 7, 8, dan ayat 10 jelas merupakan perluasan dari teks aslinya. $^{45}$

Dalam pasal 27 LXX, disebutkan bahwa segala yang tersisa di Yerusalem akan diangkut dan dibawa ke Babel. Teks Masoret membawa pesan yang sama namun menambahkan bahwa semua yang akan diangkut ke Babel itu akan dibawa kembali oleh TUHAN ke Yerusalem. Penambahan yang dilakukan oleh penyalin teks MT menunjukkan adanya kepentingan yang besar terhadap nasib sisasisa orang maupun perkakas Bait Allah di Yerusalem. Namun demikian, penambahan ini tidak memerhatikan keseluruhan konteks dan penekanan yang hendak ditunjukkan di

\footnotetext{
${ }^{43}$ Natalio F. Marcos, The Septuagint in Context: Introduction to the Greek Version of the Bible (Atlanta: Society of Biblical Literature, 2000), 81.

${ }^{44}$ Penulis membandingkan pendapat beberapa sarjana biblika dalam tafsiran masing-masing mengenai teks Yeremia 10:1-11, yakni pendapat John Bright, Jeremiah, Anchor Yale Bible Commentary (New York: Doubleday, 1986), 75-80, Peter C. Craige, Page H. Kelley dan Joel F. Drinkard, Jr., Jeremiah 1-25, Word Biblical Commentary (Dallas: Word, 1991), 154-161, serta Douglas R. Jones, Jeremiah, New Century Bible Commentary; Grand Rapids: Eerdmans, 1992), 171-178.

${ }^{45}$ Douglas R. Jones, New Century Bible Commentary: Jeremiah, 172.
} 
pasal 27. ${ }^{46}$ Yeremia dengan jelas menentang nabi-nabi palsu yang membawa "kabar pengharapan palsu” kepada Raja Zedekia. Penekanan berita yang dibawa Yeremia sangat jelas: segala bangsa telah diserahkan Tuhan ke dalam tangan Nebukadnezar, termasuk Yehuda. Ia akan membawa semua yang tersisa di Yerusalem untuk diangkut ke Babel sebagai bagian dari kehendak-Nya yang pasti akan terjadi. Septuaginta dan Gulungan Laut Mati sepakat tentang hal ini.

Selain penekanan yang berbeda, MT juga selalu memberi keterangan-keterangan sebagaimana yang ada di dalam kitab 2 RajaRaja. Dari pasal 27 dan 43 yang dibandingkan di atas, MT menjelaskan secara lengkap nama seseorang disertai jabatannya, misalnya nama Raja Yekhonya yang diangkut ke pembuangan di Babel dituliskan secara lengkap, yakni "Yekhonya bin Yoyakim, raja Yehuda." Gedalya, gubernur yang ditunjuk Nebukadnezar atas Yehuda dituliskan secara lengkap dalam pasal 43, "Gedalya bin Ahikam bin Safan." Hal tersebut berbeda dari teks Septuaginta. Klein mengatakan bahwa frekuensi perluasan nama dalam kitab Yeremia Teks Masoret sangat banyak. Ia memberi contoh nama "Yohanan bin Kareah" yang muncul sebanyak 14 kali pada pasal 40-43 selalu dengan nama ayahnya, kecuali dalam pasal 41:15 yang menggunakan nama Yohanan saja. Dalam LXX, nama tersebut muncul sebanyak 13 kali dalam konteks pasal-pasal yang sama, tetapi hanya empat kali menyebut nama Yohanan diikuti nama ayahnya. ${ }^{47}$

Tov melihat teks Yeremia dari Septuaginta (didukung oleh naskah Ibrani 4QJer ${ }^{\mathrm{b}, \mathrm{d}}$ dari Gulungan Laut Mati) berisi teks yang lebih dulu, sementara naskah Teks Masoret berisi teks yang lebih kemudian dan yang telah diperluas. Hebrew Vorlage dari naskah Septuaginta ini, sebagaimana dibahas dalam sejarahnya, berasal dari abad kedua SM..$^{48}$ Berkenaan dengan kesamaan teks Yeremia LXX

\footnotetext{
${ }^{46}$ Tov, "Septuagint as a Source," 40.

${ }^{47}$ Klein, Textual Criticism of the Old Testament, 32-33.

${ }^{48}$ Ibid. 36.
}

dan naskah Qumran, Jobes dan Silva mengutip pendapat Tov, "Two of the three fragments that have been previously labeled 4QJer', and which we now name 4QJer ${ }^{b}$ and $4 Q J e{ }^{d}$, display a very close relation with the Hebrew Vorlage of the LXX. In fact, no other Qumran text is as close to the LXX as these two fragments." 49 Teks 4QJer ${ }^{\mathrm{b}}$ dan 4QJer ${ }^{\mathrm{d}}$ adalah teks Qumran yang menunjukkan kesamaan yang sangat dekat dengan teks Septuaginta.

Teks pasal kitab Yeremia dari naskah Septuaginta dan teks Qumran diyakini berisi dan merefleksikan teks asli dari Alkitab. Hal ini dapat diketahui dari kesepakatan yang dibuat para sarjana Biblika berkenaan dengan penentuan teks asli Alkitab, sebagaimana yang telah dibahas sebelumnya. Teks Yeremia yang dipilih dari Septuaginta jauh lebih singkat dibandingkan teks Yeremia dari Teks Masoret. ${ }^{50}$ Selain itu, teks Yeremia dari Teks Masoret menunjukkan adanya bias dari penerjemah dan interpretasinya. Hal ini menyebabkan teks menjadi lebih panjang dengan tambahantambahan penjelasan teologis dan keterangan yang sifatnya memberi informasi. Teks Yeremia LXX dengan pasti menunjukkan autograf Alkitab sebab didukung juga oleh teks Yeremia dari naskah Qumran yang memiliki kesamaan.

\section{Septuaginta pada Masa Kini}

Dari penelitian dan perbandingan yang telah dilakukan, LXX telah memberikan sumbangan yang besar terhadap pencarian autograf Alkitab yang telah lama hilang itu. Beberapa teks dari naskah LXX dianggap menggunakan sumber Ibrani yang lebih tua dibandingkan MT, sebagaimana dikatakan oleh Tov bahwa Hebrew Vorlage dari Septuaginta merefleksikan perbedaan dengan Teks Masoret. ${ }^{51}$ Craig Evans mengatakan:

\footnotetext{
${ }^{49}$ Jobes dan Silva, Invitation to the Septuagint, 173.

${ }^{50} \mathrm{Tov}$ mengatakan bahwa dalam perkembangan Alkitab, elemen-elemen di dalamnya biasanya ditambahkan, bukan dihapus ("Septuagint as a Source," 37).

${ }^{51}$ Ibid., 53.
} 
The $L X X$ is an important witness to the Hebrew text that predates the Masoretes. Some of its variations from the Masoretic Text agree with readings found in the Dead Sea Scrolls. Some of its differing readings appear in the New Testament, whose authors follow the LXX in more than half of their quotations of the Old Testament. ${ }^{52}$

Evans menekankan bahwa Septuaginta adalah saksi penting terhadap teks Ibrani sebelum kehadiran MT. Sebagian dari teks LXX yang berbeda dengan MT didukung teks Gulungan Laut Mati.

Penggunaan Septuaginta untuk kepentingan kritik tekstual harus dilakukan secara teliti. Selain teks-teks seperti di dalam Yeremia yang dianggap sebagai teks asli Alkitab, beberapa teks di dalam Septuaginta justru menunjukkan pengembangan yang dilakukan oleh penerjemah, misalnya teks kitab Ayub dari Septuaginta. Memang teks ini jauh lebih pendek dari teks yang ada di dalam naskah Teks Masoret, namun dari penelitian lebih lanjut diketahui bahwa hal ini disebabkan oleh gaya parafrase penerjemah dalam menerjemahkan teks kitab Ayub. Di bagian Alkitab yang lain, misalnya dalam Ulangan pasal 32:34, kelihatan bahwa MT justru memperpendek versi panjang dari LXX dan gulungan Qumran. ${ }^{53}$

Kepentingan penggunaan Septuaginta di masa kini semakin besar. Tov melihat bahwa Septuaginta memiliki status spesial dan menyarankan, "In all these cases, the $L X X$ should be used together with the MT and some Qumran scrolls in the literary analysis of Scripture." ${ }^{54}$ Beberapa terjemahan Alkitab modern melihat kepentingan ini dan menggunakan LXX dalam penerjemahan Alkitab. Hal ini dilakukan oleh penerjemah Alkitab New Internasional Version dan Lembaga Alkitab Indonesia untuk Alkitab Terjemahan Baru bahasa Indonesia. Dalam beberapa bagian teks Alkitab, penerjemah New International

\footnotetext{
${ }^{52}$ Evans, "Introduction," 18.

${ }^{53}$ Lih. Tov, "Septuagint as a Source," 33-34.

${ }^{54}$ Ibid., 56.
}

Version menganggap teks Septuaginta sebagai "the best witness to what was original." 55

\section{Kesimpulan}

Berdasarkan penelitian terhadap Septuaginta yang telah dilakukan selama ini menunjukan bahwa Septuaginta memiliki peran yang penting dalam studi biblika. Telah cukup lama sarjana-sarjana biblika di masa lalu menganggap Septuaginta sebagai teks yang korup dan tidak dapat diandalkan dalam penelitianpenelitian teks Alkitab. Penelitian terkini yang dilakukan sarjana biblika seperti Tov telah mematahkan prasangka ini. Septuaginta dalam beberapa bagian teksnya justru lebih bergantung kepada kepada teks Ibrani yang lebih tua dan dapat diandalkan. Dukungan terhadap beberapa teks LXX ini datang dari naskah-naskah Qumran (The Dead Sea Scrolls) yang menunjukkan kesamaan yang jelas. Sejarah Septuaginta telah menunjukkan bahwa naskah Alkitab kuno ini dipandang sebagai naskah yang memiliki otoritas, paling tidak bagi komunitas orang Yahudi yang berbahasa Yunani di Aleksandria. Keyakinan ini terus dibawa oleh jemaat bahkan diakui oleh beberapa Bapa Gereja. Hal yang luar biasa adalah bahwa kutipan-kutipan dalam Perjanjian Baru terhadap teks Perjanjian Lama justru didominasi kutipan dari Septuaginta, yang tidak lain adalah terjemahan bahasa Yunani dari teks Perjanjian Lama. Dalam pelaksanaan kritik tekstual untuk mencari teks asli (autograf) Alkitab, Septuaginta telah menjadi sumber berharga bagi sarjana-sarjana biblika masa kini, di mana naskah Septuaginta digunakan bersama-sama dengan naskah Teks Masoret dan naskah Qumran. Penelitian terhadap Septuaginta harus terus dilanjutkan demi kepentingan pencarian naskah asli Alkitab.

${ }^{55}$ Ibid., 135. Bandingkan mis. teks 2 Samuel 13:34 terjemahan New International Version yang menerjemahkan langsung dari Septuaginta dengan terjemahan New King James Version yang menerjemahkan dari naskah Teks Masoret. 


\section{Daftar Kepustakaan}

Bright, John. Jeremiah. The Anchor Yale Bible Commentary. New York: Doubleday, 1986.

Craige, Peter C., Page H. Kelley, dan Joel F. Drinkard Jr. Jeremiah 1-25. Word Biblical Commentary. Dallas: Word, 1991.

Evans, Craig A. "Introduction." Dalam Exploring the Origins of the Bible: Canon Formation in Historical, Literary, and Theological Perspective, diedit oleh Craig A. Evans dan Emanuel Tov, 15-29. Grand Rapids: Baker, 2008.

Greenspoon, Leonard J. "Mission to Alexandria: Truth and Legend About the Creation of the Septuagint, the First Bible Translation.” Bible Review 5, no. 4 (August 1989): 34-37, 40-41.

Jobes, Karen H. dan Moisés Silva. Invitation to the Septuagint. Grand Rapids: Baker, 2000.

Jones, Douglas R. Jeremiah. The New Century Bible Commentary. Grand Rapids: Eerdmans, 1992.

Klein, Ralph W. Textual Criticism of the Old Testament: The Septuagint after Qumran. Philadelphia: Fortress, 1974.

Lambe, Ishak P. "Kritik Teks Naskah Perjanjian Lama: Uraian Umum tentang Kritik Teks sebagai Sebuah Metode Penelitian Kritis terhadap Naskah-Naskah Perjanjian Lama." Forum Biblika 3 (Oktober 1992): 11-32.

Marcos, Natalio F. The Septuagint in Context: Introduction to the Greek Version of the Bible. Atlanta: Society of Biblical Literature, 2000.

McDonald, Lee M. The Biblical Canon: Its Origin, Transmission, and Authority. Peabody: Hendrickson, 2007.

. "Wherein Lies Authority? A Discussion of Books, Texts, and Translations." Dalam Exploring the Origins of the Bible: Canon Formation in Historical, Literary, and Theological Perspective, diedit oleh Craig A. Evans dan Emanuel Tov, 203-240. Grand Rapids: Baker, 2008.

Murah, I Nyoman. “Kritik Teks, Apa Itu?” Forum Biblika 3 (Oktober 1992): 1-10.

Myers, Allen C., ed. The Eerdmans Bible Dictionary. Grand Rapids: Eerdmans, 1987.

Shutt, Robert J. H. "Letter of Aristeas." Dalam The Old Testament Pseudepigrapha. Vol. 2. Diedit oleh James H. Charlesworth, 7-34. New York: Doubleday, 1985.

Tov, Emanuel. "Septuagint as a Source for the Literary Analysis of Hebrew Scripture." Dalam Exploring the Origins of the Bible: Canon Formation in Historical, Literary, and Theological Perspective, diedit oleh Craig A. Evans dan Emanuel Tov, 31-56. Grand Rapids: Baker, 2008.

Ulrich, Eugene. The Dead Sea Scrolls and the Origins of the Bible. Grand Rapids: Eerdmans, 1999.

Wurthwein, Ernst. The Text of the Old Testament. Grand Rapids: Eerdmans, 1995. 